DOI: $10.20472 / S S .2019 .8 .2 .003$

\title{
METHYLPHENIDATE AND CRIME REDUCTION
}

\section{BIRGER ANTHOLZ}

\begin{abstract}
:
In a school survey, 37 out of 1066 pupils say they had attention deficit hyperactivity disorder ADHD. ADHD students who are not treated with methylphenidate show an offender rate of $68 \%$. When treated with methylphenidate it is $33 \%$, only half as high. Methylphenidate treatment halves the crime rate. That Methylphenidate is an effective anti-crime tool is confirmed by a Swedish study with adults (deviance reduction through methylphenidate, $32 \%$ for men and $41 \%$ for women). A crime decline in the bright and dark field is recognized in Germany as being worldwide since 1993, while at the same time the prescription of methylphenidate has increased nationally and internationally. From the micro-/ individual relation of the school survey and the macro-connection, i.e. the coincidence of crime reduction and methylphenidate increase, causality is derived. Methylphenidate is an important explanation for the decline in crime in the last 25 years.
\end{abstract}

\section{Keywords:}

Ritalin, methylphenidate, crime drop, orbitofrontal cortex, ADHD, deviance

JEL Classification: 112, 114, 138

\section{Authors:}

BIRGER ANTHOLZ, University of Hamburg, Germany, Email: birger.antholz@public.uni-hamburg.de

\section{Citation:}

BIRGER ANTHOLZ (2019). Methylphenidate and Crime Reduction. International Journal of Social Sciences, Vol. VIII(2), pp. 33-55., 10.20472/SS.2019.8.2.003 


\section{Introduction}

ADHD children show a high vulnerability to crime (Lundstrom et al. 2014; Neuy-Barthmann 2012). As adolescents and adults, they have a strongly increased risk of delinquent behavior (Barkley et al. 2004). The chance of delinquency is two to three times higher (Mohr-Jensen/Steinhausen 2016). This becomes visible in prison. Almost half (45\%) of all juvenile prisoners have ADHD (Retz et al. 2004; Rösler et al. 2004). Weiss et al. (1985) find in their two populations (ADHS/control group) that in a follow-up study, after 15 years $18 \%$ of ADHD sufferers were on trial, but only $5 \%$ of the control group. Manuzza et al. (1989) report a conviction rate of $28 \%$ for ADHD and $11 \%$ without ADHD among their 18-year-olds. According to a 15-year follow-up study, ADHD juvenile prisoners are 2.5 times more likely to relapse (Philipp-Wiegmann et al. 2017). As Copeland et al. (2007) describe, there are increases in the risk of crime with co-morbidity such as a disorder of social behaviour, and decreases with pure attention deficit without hyperactivity. Dalsgaard et al. (2013) find that the increase in the incarceration rate depends on the severity of ADHD.

Methylphenidate could be a factor in preventing this potentially deviant life-perspective. Children with ADHD who are treated with methylphenidate during their ADHD culmination phase are less criminal than untreated children (Belcher 2014). In this paper, it is investigated with student surveys whether methylphenidate actually achieves this crime-reduction effect, or whether authors are right to demonise Ritalin and suspect violence as a side effect (Schwind 2013, 257).

\section{State of research and question}

Methylphenidate (trade names Ritalin, Medikinet, Concerta, Equasym + other generics) is often prescribed to the 650,000 children with ADHD in Germany (Barmer Arztreport 2018). Approximately 54 million DDD (Defined Daily Dose) of $30 \mathrm{mg}$ are prescribed per year, which speaks for up to 250,000 treated ADHD pupils; about 50,000 10-14-year-old boys take it. Including the 228,000 ADHS adults, from which 80,000 get Methylphenidate, 330,000 people in Germany consume methylphenidate (Barmer Arztreport 2014). This high figure shows that an examination of the consequences would be relevant.

Internationally, there are studies that confirm the positive crime-reducing effect of methylphenidate. A Swedish study published in 2012 (Lichtenstein et al. 2012) gained a lot of attention in Germany, being discussed in the media. The Swedish approach is completely unthinkable for Germany. This is because data protection plays a different role in Sweden. Swedish researchers can use personnel numbers to identify ADHD patients in the patient registry, view their prescriptions in the prescription register and compare them with the police suspect register and the court's convict register since 1973. Due to this total data transparency, the Swedes do not need special groups, but can rely on the population. Correspondingly high numbers of cases can be realized, and just as high is the empirical weight of the study. The sample includes 25,656 Swedes diagnosed with ADHD, for whom they have the medication and crime rate for the period 2006-2009. The researchers around Lichtenstein find that 
methylphenidate reduces crime by $32 \%$ for men and $41 \%$ for women (during the application phase). An additional perspective is that in the Swedish study, those of 16 and older, i.e. adults, are involved. In this respect, it can be shown that methylphenidate also leads to an impressive reduction of crime among adults. Other Scandinavian registry studies show reduction effects in ADHD treatment with pharmaceuticals for drugs (Chang et al., 2014) and accidents (Man et al., 2015). Suicides can be lowered (Ljung et al. 2014) and thus the increased mortality of ADHD sufferers can be adapted. Ginsberg and Lindefors (2012) demonstrate in a double-blind setting with 30 prisoners that methylphenidate reduces ADHD symptoms.

Meta-analyses also show the success in crime reduction of pharmaceutical treatment of ADHD. A Canadian meta-analysis evaluated 45 randomized placebo-controlled studies from the period 1980-2005 (Pappadopulos et al. 2006). Cohen's d as an effect strength is 0.90, and proves a high aggression-reducing effect with MPH for ADHD with co-morbid disruptive behavior problems. A review by Belcher (2014) confirms the anti-crime effect of pharmacological treatment. In contrast, behavioural therapy hardly achieves success in the treatment of ADHD (Sonuga-Barke et al. 2013). The far-reaching superiority of pharmacological treatment is demonstrated by the MTA study published at the beginning of the nineties, using almost 600 ADHD children who were treated differently (see Preuss 2007). With psycho-stimulants, up to $80 \%$ were ADHD symptomfree. A double-blind study in Mannheim (Bliznakowva et al. 2007) shows the considerable application advantage of psychotropic drugs. Two meta-analyses of Klassen u.a. (1999) and van der Oord et al. (2008), both with 26 studies each, confirm the superiority of psycho-stimulants over psychotherapies. In pharmacotherapy, methylphenidate (MPH) is the gold standard from the age of six (Freyer 2017, 57). Satterfield et al. demonstrate that additional behavioural therapy at most improves the reduction of delinquency (cf. Döpfner/Lehmkuhl 2006, 658). However, this requires at least two years of therapy, so that it can be assumed that behavioral control causes the additional crime reduction. Psychosocial interventions are a much smaller attribution factor in multimodal settings. From a cost point of view (Hejduková/Kureková 2017, 33) methylphenidate with 50 Cents to 1.50 Euro / Dollar per day is considerably cheaper than psychotherapy, which costs around $5000 €$ for 50 sessions at $100 €$ each.

In the following, the research question is examined: how strongly does methylphenidate contribute to multiple pathways out of crime (Abrah Boamah 2014, 3), and is methylphenidate an effective way to lower deviance? The empirical approach is a survey of about 18-year-old high school students. The multi-topic questionnaire includes a question about ADHD and, as a followup question, possible treatment with Ritalin. There are then no clinical patients, but (typical) pupils are examined. The proportion of pupils with ADHD is around 3\% among the senior high school students surveyed - according to Schlander (2007), 2.3\% of children and adolescents are in need of ADHD treatment. Of the ADHD students, one section has taken methylphenidate and another has not. In this respect, the effect of methylphenidate on ADHD students can be tested. 


\section{Methodology: Paper and pencil student survey of 18-year-olds}

The empirical approach is based on student surveys. From 2006 to 2016, around 1000 senior high school students who come to university open days are interviewed in Hamburg almost every year. Every student entering a lecture hall receives a paper questionnaire and is asked to complete it. Before the start of the event, the open questions are entered freely, or crosses are made on closed questions. Students like to fill in questionnaires. It is a short multi-topic questionnaire that does not ask for a name or school, i.e. every student can answer anonymously. Anonymity, believed by the respondents, is important for topics such as ADHD, crime and drug treatment. For clinical studies, this cannot be guaranteed. There is a question about criminal behavior in the questionnaire. This offending question is: "Have you done anything illegal / criminal in the last 12 months? O No O Yes, namely

". Only actual crime offenses are coded (the basis of which is the criminal code, misdemeanors and misconduct are not recorded). In the year presented, the average offender rate was $22 \%$. This student survey ( $\mathrm{N}=$ 1066) also asked about ADHD: "Did you previously have ADSH (hyperactivity)? O No O Yes." $3.5 \%$ of students admit ADHD (ADSH is the former German spelling). Additionally, they ask if they have been treated with methylphenidate or not: "Did you get Ritalin? O No O Yes." At the time of the survey, the approximately 18-year-old pupils only received "Ritalin" during their methylphenidate treatment, which usually takes place between 8 and 12 years of age. For many years, Ritalin has been the generic name representing methylphenidate.

\section{Result: Less crime among methylphenidate-treated ADHD students}

Of 1066 students, 37 reported having had ADHD (3.5\%). Of these, 34 answered the Ritalin question.

Figure 1: Ritalin treatment effect on offender quota in ADHD students

\begin{tabular}{|c|c|c|c|}
\hline ADHD und & Offender & Non offender & Total \\
\hline Ritalin Yes & 2 & 4 & 6 \\
\hline Ritalin No & 19 & 9 & 28 \\
\hline
\end{tabular}

Of the 34 students, 6 received Ritalin (18\%). 28 (82\%) remained untreated. The perpetrator rate is very different in both groups. In the Ritalin-treated group (top line) of ADHD students, 2 out of 6 are offenders (33\%). In the group, treated without Ritalin, 19 out of 28 are offenders (68\%). According to the Chi-square test (Pearson), the difference in the perpetrator rate is, with an error probability of $11.4 \%$, only a short distance away from the $10 \%$ significance limit. Significant results could not be expected due to the small sample size.

As a connected measure, the Phi correlation coefficient $\Phi$ is calculated: $\Phi=(2 \times 9-19 \times 4) /[(2+19)$ $x(4+9) \times(2+4) \times 19+9)]^{0.5}=(18-76) / 45864^{0.5}=-58 / 214.16=-0.27$. Ritalin reduces the offender rate, therefore the correlation is negative. Cramer's $V$ or Eta measure only the strength 
of the relationship and, as the magnitude of $\Phi$, exhibit a correlation coefficient of $r=0.27$. This is a medium connection strength. The conversion of $\Phi=-0.27$ or here $r=0.27$ into the effect size Cohen's d results:

$$
d=\frac{(1 / 0.5 \times 0.5)^{0,5} \times 0.27}{(1-0.27)^{0,5}}=\frac{0.54}{0.8544}==>\text { Cohen's } d=0.63
$$

An effect strength of Cohen's d of 0.63 indicates an average strength.

Figure 2: Influence of methylphenidate on the offender rate of ADHD students

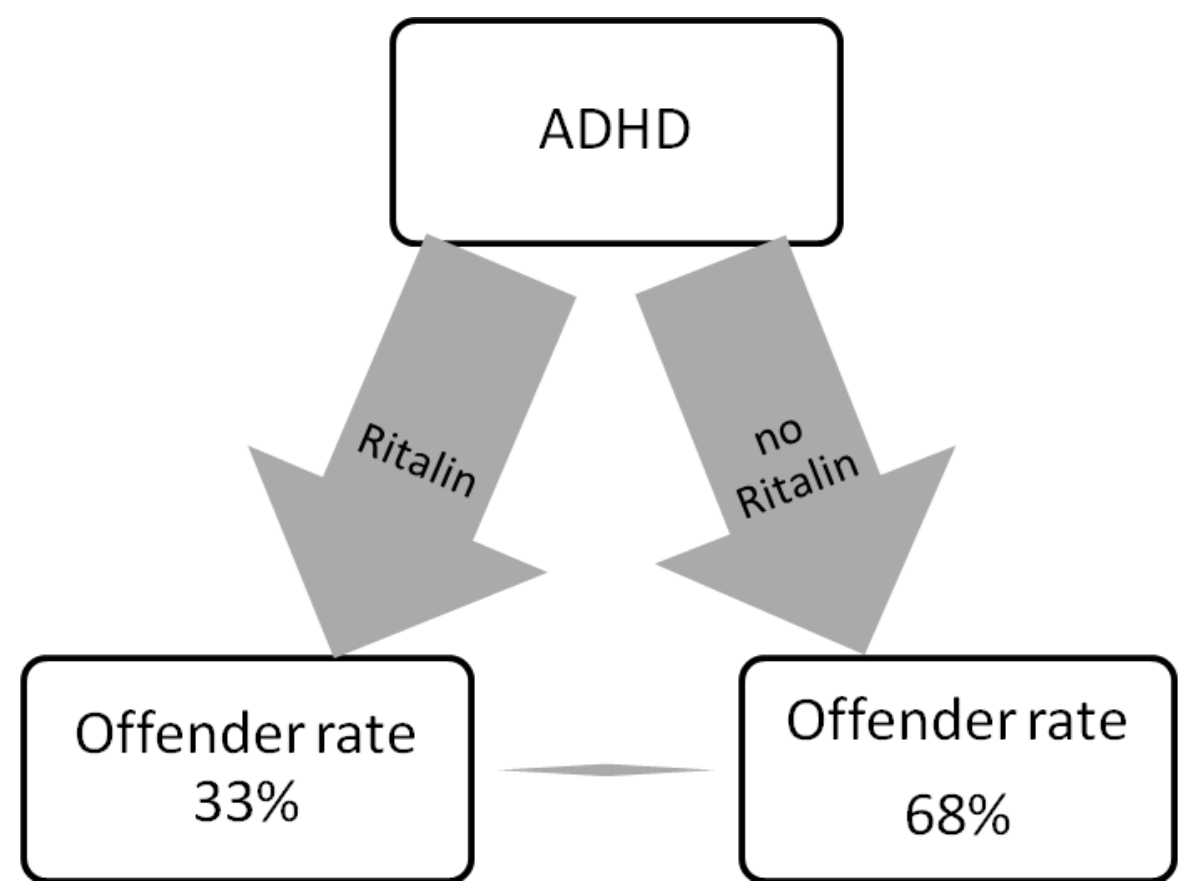

Taking into account the limited number of cases, the result of the student survey is a strong reduction in the number of offenders by methylphenidate. Compared to untreated pupils, who have a perpetrator rate of $68 \%$, the number of perpetrators is halved to only $33 \%$. The Ritalintreated pupils almost reach the average level of the students, who have an average offender rate of $22 \%$. 


\section{Discussion}

\subsection{Objections of investigation design}

Repeatedly, the small number of cases in the presented study has been criticized. However, the number of cases is not at all low, and is similar to many clinical studies, as the previously mentioned study by Ginsberg and Lindefors (2012) with an N=30 indicates. In the Cochrane meta-analysis, most of the 185 studies also include only small populations of similar magnitude the average of the cross-over studies contained therein is 49 people. In the meta-analysis of Epstein et al. (2014), the average study size is of 47 subjects.

Out of 1,066 interviewees, 34 indicate ADHD and answer the methylphenidate question. If you wanted to have a sample of a full 1000 ADHD + Ritalin respondents instead of 34, you would have had to question 31,000 students $(34 \times 1000 / 1066)$, which is completely unrealistic. The student surveys will be tackled in 2014 and 2016 by several departments of the University of Hamburg, and it is hardly possible to get 1000 respondents. Even if one were to take university information days from 30 major universities in Germany, a case number of 31,000 would hardly be achieved. 1000 students mean two weeks of data entry, with 31,000 pupils it would take more than a year to feed data into the system.

The Cochrane meta-analysis of 185 studies reveals something else. In methylphenidate studies fail the normal approach of a randomized, double-blind, placebo-controlled trial. This is because the test candidates and observers, such as parents or teachers, immediately notice when someone gets methylphenidate or a placebo. This means that there is no double-blind experiment in reality, because the two test groups are immediately distinguishable. In addition, there is often a lack of randomization, as severe ADHD patients are more likely to receive methylphenidate. Another problem of clinical studies is the short field duration, often of only a few weeks or months. In view of the fact that the normal parallel group design of psycho-pharmacological experiments with methylphenidate does not work at all (Cochrane 2015), the weaknesses of the Hamburg survey, asking non-clinical ADHD students about methylphenidate experiences in the long-term perspective appears less important.

A Cochrane review of the methylphenidate effect in adults (Epstein et al. 2014) will even be withdrawn in 2016, because clinical studies in this area are of too low a quality. In addition to the previously mentioned deficits (missing blindness, no follow-up), collusions of interests of test candidates and systematic reviewers, as well as the exclusion of patients with psychiatric comorbidity, are criticized (Boesen et al. 2017). The planned improved reissue of this meta-analysis of studies investigating the effects of methylphenidate on adults raises questions in advance. Although the parallel group design does not work for methylphenidate, despite experiments with active blindness (instead of placebo, a drug with similar (adverse) effects as methylphenidate is given), the two alternative cross-over studies (subgroup A gets methylphenidate in the first period, subgroup B the placebo; in the second period there will be a change; in 2015, 147 of 185 studies, i.e. around $80 \%$, are cross-over studies) and cluster randomised studies (assessments in which 
the allocation is based on medical centres, communities, schools or similar institutions) are excluded from the meta-analysis from the outset (Boesen et al. 2017b). The exclusion of the cross-over studies is to take place although a re-analysis of the Cochrane data found an equivalence of both experiment designs (Krogh et al. 2019). Discussions are also being held about the admissibility of co-interventions or about the common practice of enriched design (intolerance patients are excluded in advance). The extensive methodological controversy over the last Cochrane reviews of methylphenidate efficacy studies shows that hardly any study in this area is accepted by other researchers. In particular, works that judge methylphenidate positively (see Boesen et al. 2017) are rejected. Against this background, the shortcomings of the Hamburg study must be put into perspective.

\subsection{Medical explanation of the mode of action: Methylphenidate inhibits neurotransmitter overactivity}

A main objection to the Hamburg study presented here is that from a pedagogical and sociological point of view, this investigation shows a regression towards the biologisation and pathologisation of the analysis of deviance. The accusation of biologism is countered by talking about the biochemical and neurophysiological background of ADHD. Medical treatment of ADHD is common in practice. $4.4 \%$ of 5 to 14 year-olds were diagnosed with ADHD at DAK health insurance in 2011; the figure for AOK health insurance was $4.9 \%$. Half of these $-63 \%$ at DAK and $43 \%$ at AOK - were treated with methylphenidate (DAK 2015; Ärzteblatt 2014).

Pathophysiologically, in ADHD volume reductions of orbitofrontal cortex regions, cerebellum and basal ganglia are observed (Castellanos et al. 2002). Visualization studies indicate hypoactive activation patterns of prefrontal cortex regions, the anterior cingulum and associated cerebellar, parietal and striatial structures (Faraone et al. 2015). The heart of the disease ADHD is a connatal biochemical metabolic disorder, similar to diabetes mellitus (sugar disease) or hypertension (high blood pressure). In the catecholaminergic neurotransmitter system, especially that of the dopaminergic metabolism, there is dysfunction. The handicap is an overactivity of neurotransmitters, i. e. messenger substances carrying information about the synaptic gap from cell to cell. Hyperactivity leads to too many signals being passed from cell to cell, resulting in a lack of attention and urge to move. Methylphenidate reduces this sensory overload of the cells by reducing and optimizing messenger transfer. 
Figure 3: ADHD brain before (left) and after methylphenidate consumption (center and right)

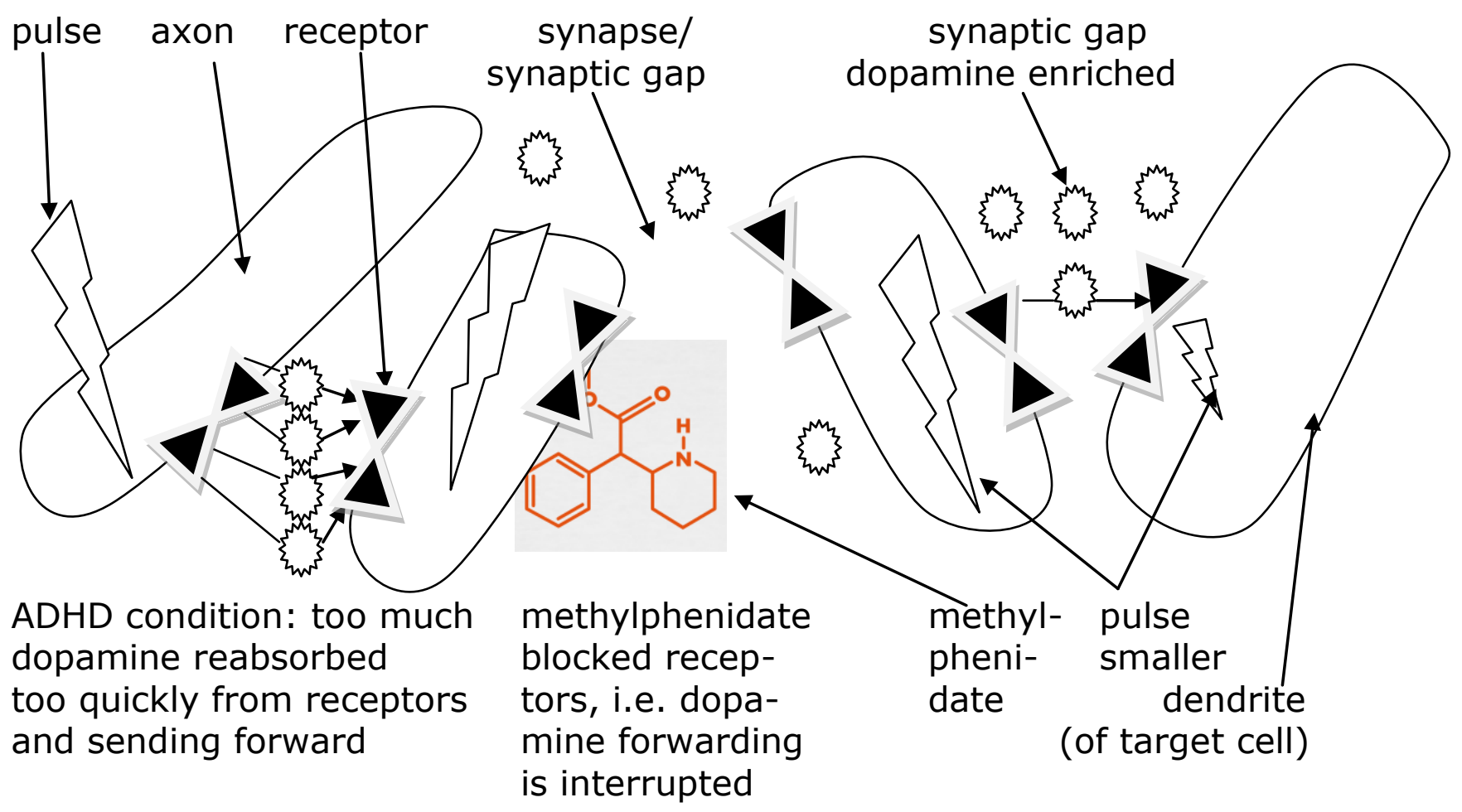

On the left side of the drawing, the status quo with ADHD is shown. The oval structures represent shortened neurons (nerve cells). In the neuronal chain, the impulse is transmitted presynaptically by the axon and received postsynaptically by the dendrite. The synaptic gap (synapse = nerve end + gap) lies between the two nerve endings (synapses). In order to overcome this, the incoming electronic signals are converted into chemical messengers (neurotransmitters). These neurotransmitters are emitted from a bulge of the presynaptic membrane of the axon, the endfeet, in order to migrate via the synaptic gap to the dendrites of the target cell. There, receptors receive the neurotransmitters. In someone with ADHD, this neurotransmitter transmission is disturbed to the extent that too many impulses are transmitted. In the drawing above, this is made clear by the four short arrows. The output pulse (shown as a thunderstorm flash because it is an electronic signal) arrives in the next nerve cell at full height or completely changed. This suffers permanently from overfiring. People can no longer coordinate their thoughts and movements purposefully.

How does methylphenidate reduce crime? Methylphenidate $\mathrm{C}_{14} \mathrm{H}_{19} \mathrm{NO}_{2}$ is a molecule that attaches to the end buttons, the dopamine transporters and, above all, the receptors. As a result, the neurotransmitters dopamine, noradrenalin and norephedrine can no longer couple. This means that they are only transmitted at a vastly reduced rate. The target cell no longer needs to absorb them to the same extent. Consequently, the concentration changes. Because fewer neurotransmitters are transmitted, less dopamine is in the target neuron, the impulse arrives there at a slower rate. Methylphenidate helps to prevent this target cell from being overloaded with 
dopamine pulses and transmitting too many electronic signals. Therefore, this cell no longer tends to exhibit overactivity. In the case of muscle cells, methylphenidate thus ends the excessive urge to move in children with ADHD. Because fewer impulses are transmitted by methylphenidate, the forwarding process can be better controlled, and the quality of forwarding increases.

This process is supported by the selective inhibition of dopamine transporters. The unimportant D2 receptors are blocked more often than the important D1 receptors. In addition, more dopamine now accumulates in the interspaces of the nerve endings, in the synaptic gap. This increased concentration facilitates the fast transmission of electronic signals. The actually chemical synapse (transformation chain of electronic impulse - chemical messenger - electronic impulse) partially becomes the electronic synapse (direct transmission of electronic impulses without conversion). As a result, the target cell is now able to recognize impulses more clearly. The amygdale, which is closely connected to the frontal cortex then becomes more capable of disposition during brain processing. Because less secondary impulses are transmitted, the previous noise is also eliminated. The cell and thus the whole human being can better concentrate on one thing. Thus, methylphenidate causes a partial blockade of the neurotransmitters, and that nerve impulses are transmitted in a lesser amount and therefore with more information clarity about the synaptic cleft to the target dendrites. In the drawing above, you can see in the right part of the picture that only a nerve impulse (arrow) is transmitted, which also only has a weakened effect in the target neuron.

The basic function of methylphenidate is to remove a genetically caused neurotransmitter defect, which manifests itself in overactivity, by blocking. Electronic signals are only transmitted via the nerve tracts and synapses in a selective manner. This allows the frontal brain to regain its control function. Individuals are given back their autonomy through their control of thought and action. This directly causes crime reduction.

\subsection{Brain pathway optimization without permanent additional methylphenidate}

The Hamburg student survey also provides information on further knowledge. In the Hamburg survey, an average of adolescents were interviewed. Their first contact with Ritalin likely took place 8-12 years ago. Methylphenidate is used only after 6 years of age, and reaches its application peak in the 4th grade when a high school recommendation is pending, i. e. at the age of 10 years. Some likely only got Ritalin during the final elementary school phase. The mediumterm effects of Ritalin medication are therefore examined in the survey. In an American study by Tye et al. (2010) it is found that methylphenidate permanently changes brain structures for the better. It is precisely this stability of brain improvement that could be confirmed by the Hamburg examination. 
Figure 4: Brain reorganisation 8-12 years after methylphenidate medication

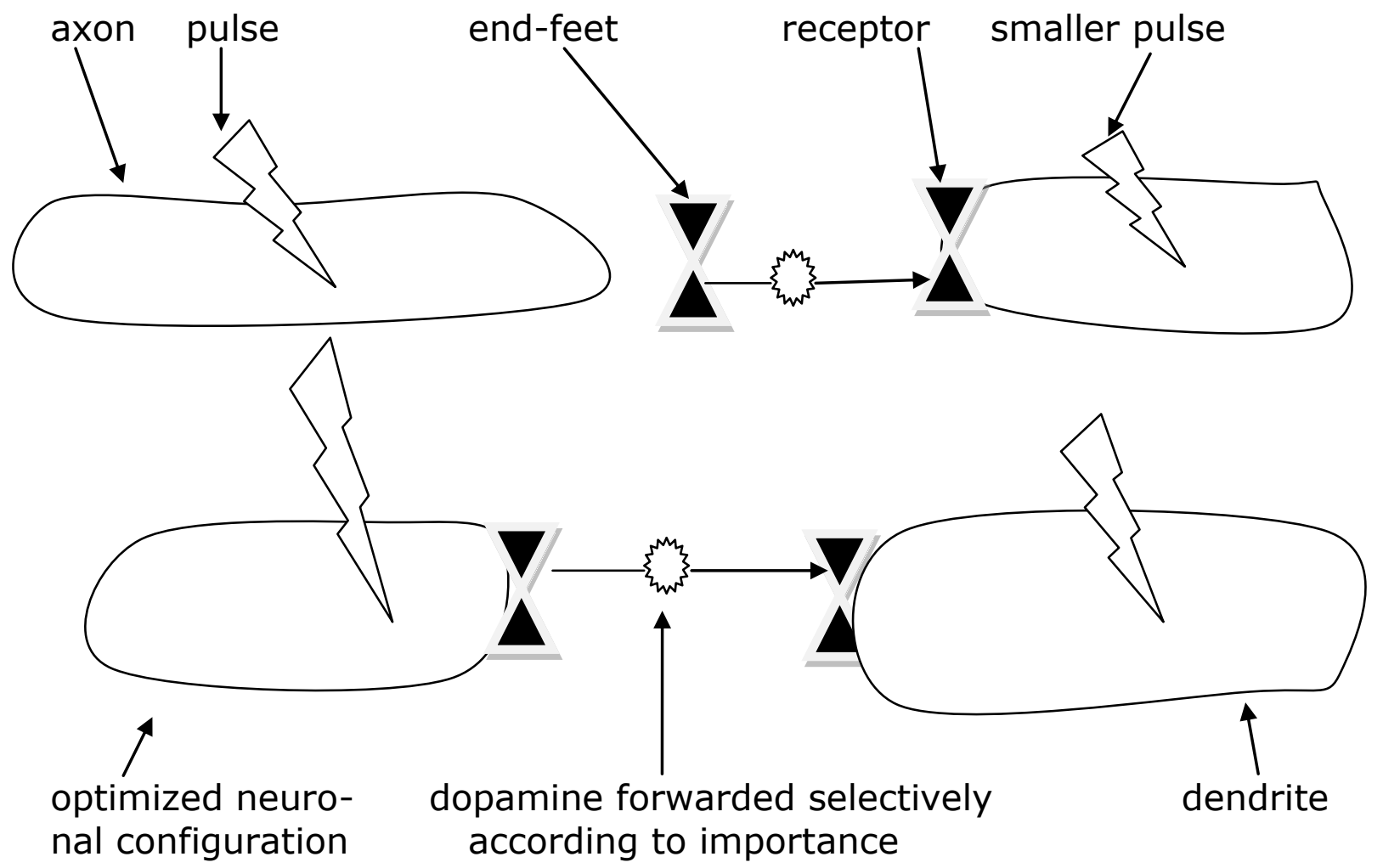

The drawing shows the four neurons from Figure 3. But there are now some times, often years of methylphenidate consumption. Over this time methylphenidate has steered nerve impulse transmission into more optimal pathways. It has slowed down the number of pulses and filtered out the important impulses for forwarding. As Tye et al. (2010) find out, the neurons have relocated themselves according to optimal forwarding. Instead of criss-cross as in ADHD patients, a regulated structure is now available. This optimizes signal forwarding. The new findings, also evident in the Hamburg student survey, show that more optimal brain structures are retained when methylphenidate is discontinued. The nerve pathways form a new and better neuronal network by methylphenidate, which functions permanently. This explains why the crime reduction continues beyond the pure methylphenidate consumption period. The Hamburg pupils are likely to have had their Ritalin experience, which began 8-12 years ago, often already longer ago. Even so, their $33 \%$ incidence rate is only half as high as that of non-Ritalin patients at $68 \%$. The confirmed finding is that methylphenidate-induced brain enhancements and the consequent lowering of deviances are permanent. An optimization of cortical brain regions is also confirmed by a study by Frodl / Skokauskas (2012).

Such brain structure-creating processes have long been known through pain research. In cases of acute pain, e. g. through lesion (injury), analgesics (pain relievers) should suppress the pain so that no pain pathways develop. Otherwise, the nerve cells would also fire pain impulses into the previously created neuronal pathways if the acute cause disappeared for some time. The 
Hamburg student survey and two neurological studies cited show that such permanent brain restructuring processes are also modulated by methylphenidate. In the case of methylphenidate, however, these new brain structures are completely positive, unlike those in the case of pain pathways. The cerebral pathways improved by methylphenidate stabilize the personality so that less crime is committed in the long term. The prefrontal brain areas can perform life-long executive functions, such as interference control and arousal control more effectively.

The Hamburg student survey also shows that there are no negative consequences of Ritalin medication. It is asked as a follow-up question to ADHD and Ritalin: "Do you have after-effects of this today? O No O Yes, namely ". No one who took Ritalin cited after-effects. About $10 \%$ of those with ADHD who have not received methylphenidate say that they suffer from today's effects ("very fidgety, restless, twitchy").

The result of persistent optimization of orbitofrontal cortex regions is similar to a study by Biederman et al. (2009). They examined 112 white boys with ADHD at a 10-year interval. This is more ADHD sufferers than in the Hamburg student survey, in which only 37 ADHD students were included (in Hamburg, also girls; skin color, of course, plays no role). Similar to the students in Hamburg, one part of them received methylphenidate treatment and the other did not. Biederman examined these boys 10 years after treatment at an average age of 22 years. This corresponds roughly to the Hamburg concept of interviewing 18-year-olds, most of whom may have started with Ritalin 10-12 years ago. In their follow-up study, Biederman et al. found that after 10 years, children treated with methylphenidate suffer less frequently from psychiatric diseases than children who have not been treated. In the medium term, methylphenidate thus protects against psychic illnesses frequently occurring in ADHD patients and, if they persist for more than 6 months, against mental and psychological disabilities. There is no rebound effect when methylphenidate is removed. Drug treatment prevents opposition disorders in childhood from turning later into a co-morbid disorder such as criminality. In the already mentioned metaanalysis, which evaluates 185 ADHD studies (including 175 with placebo), the Danish research group found positive effects during the application of methylphenidate, but believed that studies on long-term effects are lacking (Cochrane 2015).

Three recent ADHD research papers (Moffit et al., 2015, Caye et al. 2016, Agnew-Blais et al., 2016) are currently being discussed (Klein 2017). In these studies the researchers noted that for some of the respondents, ADHD was not established until adulthood. This could fit in with the fact that Antholz (2015) suggested that the previous idea of a unimodal course of crime in the perspective of life should be extended to a two-peak crime course (Double Peak Age Crime Curve). In pupils, surveys in 2006-2014 (each N>1000) it was found that, in addition to the wellknown deviance climax at the age of 15-16 years, young adults at the beginning of 20s are again particularly crime-prone. Perhaps one factor in this is the onset of ADHD in adulthood in some individuals, which has now been observed in the three studies. 


\section{Conclusion: Methylphenidate increase parallel to crime decline}

From 1993, the sales of methylphenidate have been increasing rapidly both nationally and internationally (INCB 2014, 38). At the same time, crime has been falling in Germany and worldwide since 1993. Because the increase in prescriptions of methylphenidate and the decrease in crime take place in parallel, it must be assumed that there is a cause-and-effect relationship between the two. Such a connection is evidenced in chapter 3 of the pupil survey at the individual data level by halving the crime rates among ADHD students treated with methylphenidate. In the following, the increase in methylphenidate consumption in Germany from 1993 onwards is contrasted with the development of crime in the brightfield (police crime statistics) and darkfield (offender and victim surveys).

Figure 5:1993-2018 Consumption of methylphenidate in Germany, victim rate (university student surveys in Hamburg), suspected children in per thousand according to police crime statistics, offender rate (university student surveys in Giessen)

\begin{tabular}{|c|c|c|c|c|c|}
\hline year & $\begin{array}{l}\text { Methy- } \\
\text { phe- } \\
\text { nidate } \\
\text { Ger- } \\
\text { many } \\
\text { in lb }\end{array}$ & $\begin{array}{l}\text { Methyl- } \\
\text { phe- } \\
\text { nidate } \\
\text { Germany } \\
\text { in kg }\end{array}$ & $\begin{array}{l}\text { victim rate } \\
\text { survey } \\
\text { Hamburg } \\
\text { students } \\
\text { in \% }\end{array}$ & $\begin{array}{l}\text { suspected } \\
\text { children per } \\
1000 \\
\text { in police } \\
\text { crime } \\
\text { statistics }\end{array}$ & $\begin{array}{l}\text { offender } \\
\text { rate } \\
\text { survey } \\
\text { Giessen } \\
\text { students } \\
\text { in } \% \\
\end{array}$ \\
\hline 1993 & 75 & 34 & & 15,68 & 40,4 \\
\hline 1994 & 93 & 42 & & 17,69 & 37,1 \\
\hline 1995 & 128 & 58 & & 18,55 & \\
\hline 1996 & 194 & 88 & & 20,92 & 36,8 \\
\hline 1997 & 262 & 119 & 27,5 & 22,67 & \\
\hline 1998 & 381 & 173 & & 24,17 & \\
\hline 1999 & 534 & 242 & & 23,41 & 31,9 \\
\hline 2000 & 1021 & 463 & & 22,74 & 34,6 \\
\hline 2001 & 1329 & 603 & & 22,92 & 38,6 \\
\hline 2002 & 1385 & 628 & & 22,27 & 35,1 \\
\hline 2003 & 1620 & 735 & 23,3 & 21,47 & 33,9 \\
\hline 2004 & 1989 & 902 & & 20 & 33,8 \\
\hline 2005 & 2299 & 1043 & & 18,15 & \\
\hline 2006 & 2692 & 1221 & 20,3 & 18,19 & 24,8 \\
\hline 2007 & 3150 & 1429 & 16,9 & 18,61 & 24,3 \\
\hline 2008 & 3565 & 1617 & & 18,79 & 29 \\
\hline 2009 & 3825 & 1735 & & 18,01 & \\
\hline 2010 & 3880 & 1760 & & 17,16 & \\
\hline 2011 & 3948 & 1791 & & 16,12 & \\
\hline 2012 & 4054 & 1839 & 14,6 & 14,48 & \\
\hline 2013 & 3975 & 1803 & & 12,95 & 23,8 \\
\hline 2014 & 3783 & 1716 & & 12,32 & \\
\hline 2015 & 3616 & 1640 & & 11,08 & \\
\hline 2016 & 3527 & 1600 & & 10,40 & 20,9 \\
\hline 2017 & & & & & \\
\hline 2018 & & & 14,5 & & \\
\hline
\end{tabular}


Figure 6: Increase of methylphenidate from 1993 to today and simultaneous decrease of crime (regression coefficient $r=-0.9$ )

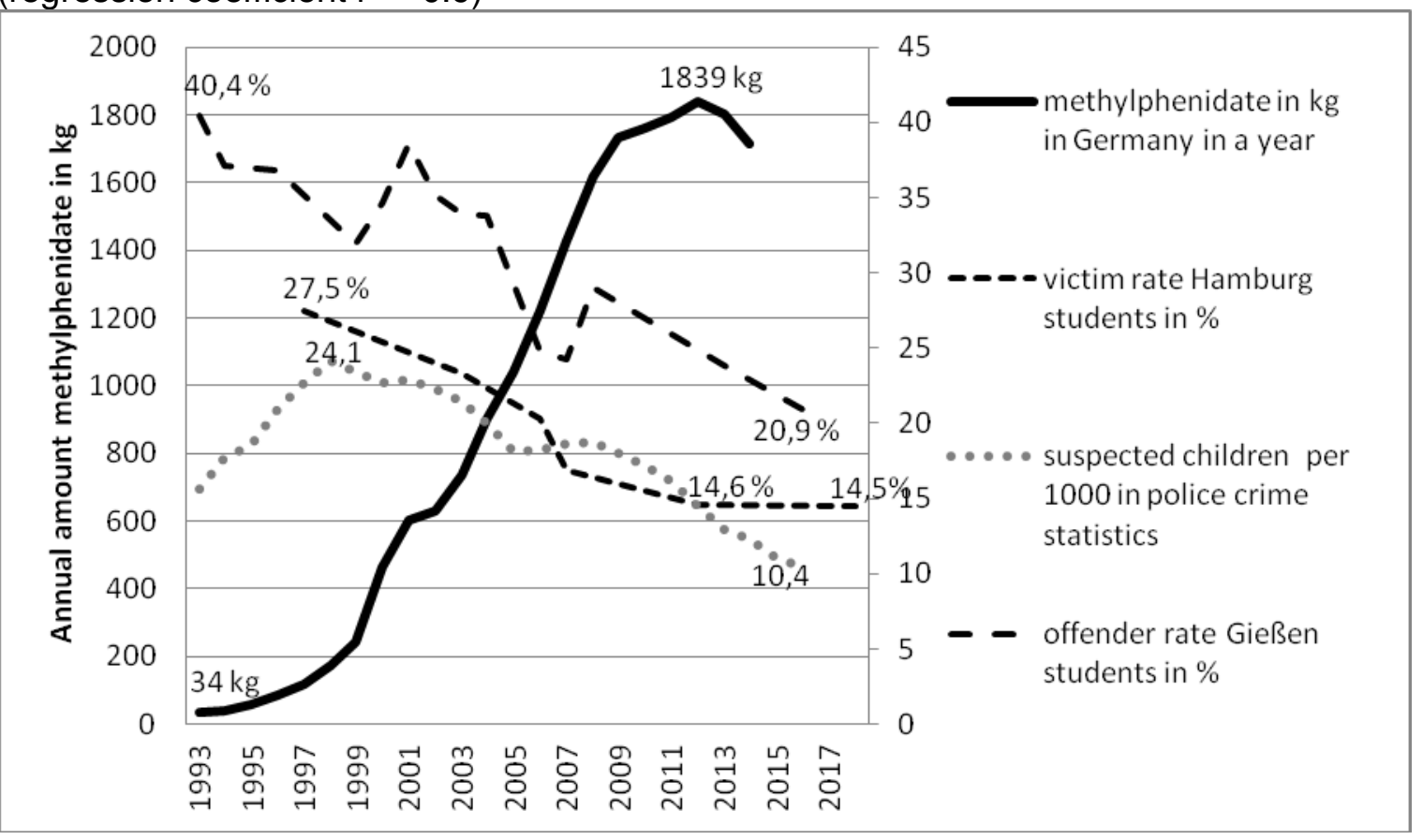

Source: Federal Institute for Drugs and Medical Devices (German abbreviation: BfArM; old name: Federal Opium Office). Despite multiple correspondence, BfArM does not want to announce a methylphenidate result for 2015, 2016, 2017 etc. For these years, the numbers from the Prescription-Report increased by 5\% (annual average difference 2005-2014). Hamburg Student Survey own survey with $\mathrm{N} \approx 1000$ each. TVBZ children according to PKS 1993-2016. Giessener delinquency surveys 1976/77 to 2004/05 by Arthur Kreuzer, 2013 and 2016 own surveys

In 1993, only 75 pounds (34 kilograms) of methylphenidate are given as medicine in Germany. In $1993,40.4 \%$ of students from Giessen identify themselves as perpetrators in a survey. In 2014, the amount of methylphenidate in Germany has risen to $3783 \mathrm{lb}(1716 \mathrm{~kg})$. The number of offenders halved to $20.9 \%$ in the self-examined Giessen survey in 2016. If the missing intermediate values of the Giessener survey series are supplemented, the correlation coefficient according to Pearson 1993-2014/16 is $r=-0.888$. If methylphenidate is interpreted as an independent variable and crime as a dependent variable, a high regression coefficient of $r=-0.9$ shows a statistically close correlation between the two variables.

The increase in methylphenidate takes place from 1993 to the maximum 2012 at $4054 \mathrm{lb}$ (1839 $\mathrm{kg}$ ). In a self-administered victim survey, in which Hamburg students are asked whether they have been victims of crime in the last 12 months, the victim rate was $27.5 \%$ in 1997 and fell to $14.6 \%$ in 2012 . If the intermediate survey values are supplemented by linear interpolation, the correlation coefficient is $r=-0.994$ (error probability $0.00 \%$; 1997-2012). A strong increase in methylphenidate is accompanied by a sharp drop in crime.

Official police statistics also show a strong decline in crime among children aged 8-13 years - a therapeutic focus group of methylphenidate. In 1998, $2.417 \%$ of children are registered as suspects, compared to $1.040 \%$ in 2016, which is (around) half as many. Between 1998 and 2014, 
the regression coefficient is -0.906. As in the Hamburg student survey, a cross-sectional comparison shows a halving of the crime rate with a strong increase in the use of methylphenidate in a longitudinal comparison.

Even countries such as the USA, which, unlike Germany, rely on repression (2.2 million prison inmates) and the continued beating of children $(85 \%$ of parents still carry this out; Pfeiffer/Heitmüller 2013), also have an impressive decrease in crime. U. S. violent crimes fell from 1992 1,932,274 police-registered crimes to 2016 1,248,185 (FBI 2017). At the same time, the consumption of methylphenidate has increased fourteenfold in the last ten years (Gehrke 2018). Instead of just over 200,000 in Germany, 6 million children and adolescents take methylphenidate in the USA (Zittlau 2015).

The high efficiency of methylphenidate stems from the fact that it is possible to specifically target intense offenders who are particularly relevant to delinquency. Almost all intensive offenders have already been noticed in kindergarten, many of them by ADHD symptoms such as hyperactivity. Untreated, the lack of impulse control persists until adulthood. At least $3 / 4$ of children with ADHD suffer from ADHD as adults (Gawrilow 2012, 102). The Philadelphia study (Wolfgang/Figlio/Sellin 1972; Tracy/Wolfgang/Figlio 1990) as well as Boers/Reinecke in the Duisburg study shows that $6 \%$ of the perpetrators of a cohort are responsible for half of all crimes and three-quarters of violent offences (Boers et al. 2009, 15). Because methylphenidate dissuades these intensive offenders from the pre-programmed crime career, it is an efficient drug. It tackles crime at its roots, namely among the renewable (intensive) criminals. ADHD patients are younger in offences (Ziegler et al. 2003), relapse more quickly (Philipp-Wiegmann et al. 2017) and more frequently (Young et al. 2015). Similarly, children brought up in an institution with an average ADHD rate of 24\% (Fegert/Trott 2007) could be target-oriented treated with methylphenidate and thus discouraged from a potential crime career (Ostendorf 2011, 62).

The well-known crime theory General Theory of Hirschi / Gottfredson from 1990 provides a monocausal crime explanation: crime is caused by a lack of self-control. Methylphenidate is the salutary answer to this major crime explanation. Methylphenidate restores self-control to those affected. Because methylphenidate inhibits the hyperactive cortex regions, ADHD people regain their cognitive and emotional impulse control. Malfunctioning of the basal ganglia and the cognitive and motoric regulation system of the cortico-striato-palido-thalamo-cortical control circuits are normalized (Banaschewski et al. 2005).

The Barmer GEK health insurance survey shows the methylphenidate prescriptions per region in a map. It is noticeable that in the east and in the north of Germany little, around half as much as in the federal average, is prescribed. This is attributed to the low density of doctors. Conversely, a lot of methylphenidate is prescribed in Bavaria, especially in the north, and in RhinelandPalatinate. The prescription stronghold is the city Würzburg (because of an ADHD clinic). The 
spatial distribution correlates inversely with the distribution of crime according to police crime statistics. There, the eastern and northern parts of Germany are regarded as highly charged in terms of crime, while the southern part of Germany, especially Bavaria, has hardly any crime. Mecklenburg-Western Pomerania gives the least methylphenidate to ADHD children and adolescents and has 20167165 offences per 100,000 inhabitants. Bavaria prescribes the second most methylphenidate and has only 4785 PKS cases per 100,000 inhabitants. The prescription stronghold Würzburg has 8557 crime cases per 100,000 inhabitants. Berlin, which is in the national average for methylphenidate, reports twice as much crime at 15,700 (all figures without violations of immigration law).

Internationally, (methylphenidate data from Sarnes 2013, 75 f.) similar geographical methylphenidate crime contexts can be observed, e. g. in Iceland and Italy. Methylphenidate is most commonly prescribed in the world in Iceland and Iceland "has one of the lowest crime rates in the world" (Henke 2017). For a long time, Italy has not allowed methylphenidate at all. From 2002 to 2012, on average of 654 people are murdered in Italy per year and not 2 per year as in Iceland (Eurostat 2015). The anti-crime effect of methylphenidate can also be seen in the comparison of Norway and Sweden, which are otherwise quite similar countries. In Sweden, methylphenidate has only been prescribed very restrictively for decades. This could be one of the reasons why crime in Norway, measured in the number of police crime statistics over the past decades, is barely half as high as in Sweden (Bondeson 2009, 615).

The movement against Ritalin leads from 2009 to admission restrictions in Germany. At the request of the European Commission, a European risk assessment procedure for methylphenidate-containing medicinal products was launched in June 2007. On $27^{\text {th }}$ May 2009, this led to a decision from the Commission on the authorization of medicinal products for human use containing the active substance methylphenidate under Article 31 of Directive 2001/83 / EC of the European Parliament and of the Council. In the appendix of the new risk assessment, it is written that "the treatment requires the supervision of a specialist in behavioural disorders in childhood". As a result, by $22^{\text {th }}$ June 2009 the Federal Institute for Drugs and Medical Devices (BfArM) ordered the implementation of the decision of the European Commission of $27^{\text {th }}$ May 2009 on methylphenidate. The decision contains changes to the technical information and package insert. The new drug information requires treatment to be conducted under the supervision of a specialist in childhood behavioural disorders. A year later, another German authority, the Federal Joint Committee, restricted the release of methylphenidate. From $1^{\text {st }}$ December 2010, only children and youth doctors and specialists for children and youth psychiatry and psychotherapy in multimodal settings (behavioural therapy coupling) have been allowed to prescribe methylphenidate. Because the waiting period, especially with paediatric psychiatrists, for an appointment is many months - already five months on average for adults (Weydt 2018) the methylphenidate increase has been stopped from 2010. After the peak year 2012 at $4054 \mathrm{lb}$ (1839 kg), there has been a decline from 2013 onwards to $20163527 \mathrm{lb}(1600 \mathrm{~kg})$. Up to 2009, 
approximately $35-45 \%$ of the prescriptions were carried out by general practitioners / family physicians and specialists (German Bundestag 2006), who can no longer prescribe from the end of 2010. Because private and non private patients receive an appointment with the child and adolescent psychiatrist at different times, this additionally leads to social injustices. Land areas are underserved. As a result, some ADHD children are now left untreated. This eliminates their deviance reduction. This is unfavourable, because ADHD crime offenders stand for reactive impulsive violence and affect acts (Retz/Rösler 2010). These affect third parties (Ginsberg et al. 2013). The number of intentional simple bodily injury cases has risen from 369,709 in 2009 to 406,038 in 2016 in police crime statistics.

The 72,204 institutional children are particularly affected by the reduced methylphenidate release. They have only limited access to child and adolescent psychiatrists, because a visit to a doctor is difficult to organise and because institutional home managers are afraid of losing the children, for whom the youth welfare office pays around 50,000 Euros per year (Antholz 2017, 300), for a child and adolescent psychiatric institution. Only half of all institutional home children with mental disorders receive medical treatment (Nützel et al. 2005). Even before the increase in the number of children with ADHD, only $20 \%$ of children in institutional homes were treated with methylphenidate (Fegert 2009, 122). Although it is known that institutional children are predisposed to subsequent crime (Farrington, 1997; Meier 2016, 182), simple methylphenidate prophylaxis has become even more difficult since 2009/2010. At the same time, the number of removals of children from families by the youth welfare office has risen sharply from 25,664 in 2005 to 84,230 in 2016 and, as a result, the number of children in institutional care homes has risen by $37 \%$ since 2007 . More and more children in institutions are treated more and more poorly with methylphenidate - a new crime problem is therefore being produced in Germany.

There is no empirical evidence for the non-treatment of some ADHD children initiated by the Federal Opium Office and the Federal Joint Committee. On the contrary, the MTA study with 579 ADHD subjects, as well as other follow-up studies (Satterfield et al. 2007), validated the high efficacy of methylphenidate even without cognitive behavioral therapy (see Banaschewski 2009). New studies show the improved efficacy of the long-acting, two-phase methylphenidate preparations now used (Haertling et al. 2015). A meta-analysis of the life span studies shows that in addition to the severity of ADHD, the treatment is the predictor of persistence of deviant behavior (Caye et al. 2016).

From the Hamburg student surveys of 2006 to 2016, one gets the impression that since the change of prescription practice of methylphenidate, the decline in crime has paused. In 2006, the victim rate was 10\%, in $20097.8 \%$, in $20107.4 \%$. Thereafter, the values are higher again: 2011 10.5\%, $201211 \%, 2014$ 9.6\%. All in all, from 2010, when the ADHD dose of methylphenidate no longer increases properly, the victim rate is higher than before. The decline in crime stagnates in the Hamburg student survey series. In 2012 the victim rate is $14.6 \%$ and in $201814.54 \%$. In 
police crime statistics, crimes increased from 5.93 million to 6.37 million from 2010 to 2016. This may suggest that there is an inverse proportional relationship between methylphenidate and crime. For twenty years, methylphenidate has contributed to crime reduction. Since the methylphenidate prescriptions are declining, delinquency is increasing again.

\section{References}

Abrah Boamah, P. (2014). Transitions in Offending Trajectories; Shared Experiences of Juvenile Delinquents. International Journal of Social Sciences, III(5), 1- 9.

aerzteblatt (2014). Weniger Ritalin-Verordnungen durch ADHS-Programm der AOK. Ärzteblatt. 25.04.2014, www.aerzteblatt.de/nachrichten/58453/Weniger-Ritalin-Verordnungen-durchADHS-Programm der AOK [03.03.2018]

Agnew-Blais, J.C., Polanczyk, G.V., Danese, A., Wertz, J., Moffit, T.E., \& Arseneault L. (2016). Evaluation of the persistence, remission, and emergence of attention-deficity/hyperactivity disorder in young adulthood, JAMA Psychiatry 73, $713-720$. https://doi.org/10.1001/jamapsychiatry.2016.0465

Antholz, B. (2015). Double-Peak-Age-Crime-Curve. Zweigipfelige Alterskriminalitätskurve. Die Polizei 106 (4), 118-120.

Antholz, B. (2017). Kindesinobhutnahmen 1995-2015. Zeitschrift für Kindschaftsrecht und Jugendhilfe 12 (8), 294-302.

Banaschewski, T., Hollis, C., Oosterlaan, I., Roeyers, H., Rubia, K., Willcutt, E. u.a. (2005). Towards an understanding of unique and shared pathways in the psychopathophysiology of ADHD. Developmental Science 8, 132-140. https://doi.org/10.1111/j.14677687.2005.00400.x

Banaschewski, T. (2009). Aufmerksamkeitsdefizit-Hyperaktivitätsstörungen - State of the Art. In Häßler, F. (Hrsg.), Das ADHS Kaleidoskop. State of the Art und bisher nicht beachtete Aspekte von hoher Relevanz (1-5). Berlin: Medizinisch Wissenschaftliche Verlagsgesellschaft. https://doi.org/10.32745/9783954661886-1

Barkley, R.A., Fisher, M., Smallish, I., \& Fletcher, K. (2004). Young adult follow-up of hyperactive children: antisocial activities and drug use. Journal Child Psychology Psychiatry 45, 195211. https://doi.org/10.1111/j.1469-7610.2004.00214.x

Barmer GEK (2016). Barmer GEK Arztreport 2016. Auswertungen zu Daten bis 2014. Schwerpunkt Alter und Schmerz.

https://www.barmer.de/blob/36738/41528a9e5704bb8d47e25e00707af4ba/data/pdfarztreport-2016.pdf [03.03.2018]

Belcher, J.R. (2014). Attention deficit hyperactivity disorder in offenders and the need for early intervention. International Journal of Offender Therapy and Comparative Criminology 58(1), 27-40. doi: 10.1177/0306624X12465583. Epub 2012 Dec 6. https://doi.org/10.1177/0306624X12465583 
Biederman J., Monuteaux, M.C., Spencer, T., Wilens, T.E., \& Faraone, S.V. (2009). Do stimulants protect against psychiatric disorders in youth with ADHD? A 10-year follow-up study. Pediatrics 124, 71-78. https://doi.org/10.1542/peds.2008-3347

Bliznakowva, L., Gerstner, S., Schmidt, M.H., \& Becker, K. (2007): Der MethylphenidatDoppelblindversuch - Indikation und Durchührung. Klinische Pädiatrie 219, 9-16. https://doi.org/10.1055/s-2005-836823

Boers, K., Reinecke, J., Bentrup, C. \& Kunadt, S. (2009). Entstehung und Verlauf von Jugendkriminalität. Erkenntnisse einer Duisburger Längsschnittstudie. der Kriminalist, ohne Jahrgangsangabe (7/8), 14-18.

Boesen, K., Saiz, L.C., Erviti, J., Storebø, O.J., Gluud, C., Gøtzsche, P.C., \& Jørgensen, K.J. (2017). The Cochrane Collaboration withdraws a review on methylphenidate for adults with attention deficit hyperactivity disorder. Evid based Med. 22 (4), 143-147. Doi: 10.1136 / ebmed-2017-110716.

Boesen, K., Danbourg, B.P., Götzsche, P.C., \& Jørgensen, K.J. (2017b). Extended-release methylphenidate for attention deficit hyperactivity disorder (ADHD) in adults. Cochrane Developmental, Psychosocial und Learning Problems Group. Doi: 10.1002 / 14651858.CD012857.

Bondeson, U.V. (2009). Crime and Justice in Scandinavia. In Schneider, H.J. (Hrsg.), Internationales Handbuch der Kriminologie: Band 2: Besondere Probleme der Kriminologie (413-434). Berlin: De Gruyter.

Castellanos, F.X., Lee, P.P., Sharp, W., Jeffries, N.O., Greenstein, D.K., Clasen, L.S., \& Rapoport, J.L. (2002). Developmental trajectories of brain volume abnormalities in children and adolescents with attention-deficit/hyperactivity disorder. JAMA Psychiatry 288, 17401748. https://doi.org/10.1001/jama.288.14.1740

Caye, A., Rocha, T.B.-M., Anselmi, L., Murray, J., Menezes, A.M., Barros, F.C., \& Steinhausen, H.-C. (2016). Attention-deficit/hyperactivity disorder trajectories from childhood to young adulthood: evidence from a birth cohort supporting a late-onset syndrome. JAMA Psychiatry 73(C), 705-712. https://doi.org/10.1001/jamapsychiatry.2016.0383

Caye, A., Swanson, J., Thapar, A., Sibley, M., Arseneault, L., Hechtman, L., Arnold, L.E., Niclasen, J., Moffin, T., \& Rohde, L.A. (2016). Life Span Studies of AHDH - Conceptual Challenges and Predictors of Persistence and Outcome. Current Psychiatry Report 18 (12), 111. Doi 10.1007/s11920-016-0750-x.

Chang, Z., Lichtenstein, P., Halldner, L., D’onofrio, B., Serlachius, E., Fazel, S., \& Larson, H. (2014). Stimulant ADHD medication and risk for substance abuse. Journal Child Psychology Psychiatry 55, 878-885. https://doi.org/10.1111/jcpp.12164

Cochrane Collaboration (2015). Methylphenidate for children and adolescents with attention deficit hyperactivity disorder. Cochrane Database of Systematic Reviews. Doi: 10.1002/1465 1858.CD009885.pub2.

Copeland, W.E., Miller-Johnson, S., Keeler, G., Angold, A., \& Costello E.J. (2007). Childhood psychiatric disorder and young adult crime: A prospective, population-based-study. 
$\begin{array}{llll}\text { American Journal of } & \text { 1668-1675. }\end{array}$ https://doi.org/10.1176/appi.ajp.2007.06122026

DAK (2015). Zappelkinder bekommen weniger ADHS-Pillen. DAK-Gesundheit: Ärzte verordnen seltener Ritalin. https://www.dak.de/bundes-themen/ADHS-Verordnungen-154818.html [07.08.2017]

Dalsgaard, S., Mortensen, P.B., Frydenberg, M., \& Thomsen, P.H. (2013). Long-term criminal outcome of children with attention deficit hyperactivity disorder. Criminal Behaviour and Mental Health 23, 86-98. https://doi.org/10.1002/cbm.1860

Döpfner, M., \& Lehmkuhl, G. (2006). Aufmerksamkeitsdefizit-/Hyperaktivitätsstörung Neuropsychologie. In Förstl, H., Hautzinger, M., \& Roth, G., Neurobiologie psychischer Störungen (671-690). Heidelberg: Springer Medizin. https://doi.org/10.1007/3-540-308873_18

Epstein, T., Patsopoulos, N.A., \& Weiser, M. (2014). Immediate-release methylphenidate for attention deficit hyperactivity disorder (ADHD) in adults. Cochrane Developmental, Psychosocial and Learning Problems Group. Doi: 10.1002/14651858.CD005041.pub2.

Eurostat (2015). File: Homicides recorded by the police, 2002-12. http://ec.europa.eu/eurostat/statistics-

explained/index.php/File:Homicides_recorded_by_the_police,_2002-12_YB14-de.png [6.8.2017]

Faraone, S.V., Asherson, P., Banaschewski, T., Biederman, J., Buitelaar, J.K., Ramos-Quiroga, J.A., \& Franke, B. (2015). Attention-deficit/hyperactivity disorder. Nature Reviews Disease Primers 1, 15020. https://doi.org/10.1038/nrdp.2015.20

Farrington, D.P. (1997). Childhood risk factors and risk-focused prevention. In Maguire, M, Morgan, R., \& Reimer, R. (Ed.), The Oxford Handbook of Criminology (2. ed.) (361-408). Oxford u.a.: Clarendon Press.

FBI (2017). Uniform Crime Reporting Statistics 2016. https:/ucr.fbi.gov/crime-in-theu.s/2016/crime-in-the-u.s.-2016/topic-pages/violent-crime [03.03.2018].

Fegert, J.M., \& Trott, G.E. (2007). Psychostimulanzientherapie der ADHS. Ulm: Universitätsklinikum Ulm.

Freyer, M. (2017). ADHS-Therapie. Erweiterte Therapieoption im multimodalen Konzept durch Amphetamine. Kinder- und Jugendmedizin 17, 56-57.

Frodl, T., \& Skokauskas, N. (2012). Meta-analysis of structural MR1 studies in children and adults with attention deficit hyperactivity disorder indicates treatments effects. Acta Psychiatrica Scandinavica 125, 114-126. https://doi.org/10.1111/j.1600-0447.2011.01786.x

Gawrilow, C. (2012). Lehrbuch ADHS. München. Reinhardt.

Gehrke, B. (2018). Methylphenidat in USA das „Koks für Kinder“. www.medizin.de/ratgeber/methylphenidat.html. [03.03.2018].

German Bundestag (2006). Drucksache 16/3394, Antwort der Bundesregierung auf die Kleine Anfrage der Abgeordneten Dr. Harald Terpe, Kai Boris Gehring, Birgitt Bender, weiterer Abgeordneter und der Fraktion BÜNDNIS 90/DIE GRÜNEN - Drucksache 16/3045 - 
Verschreibung von Medikamenten an Kinder und Jugendliche bei AufmerksamkeitsdefizitHyperaktivitätsstörung, 13. 11. 2006.

Ginsberg, Y., \& Lindefors, N. (2012). Methylphenidate treatment of adult male prison immates with attention-deficit hyperactivity disorder: randomised double-blind placebo-controlled trial with open-label extension. British Journal of Psychiatry 200 (1), 68-73. Doi: 10.1192/bjp.bp.111.092940.Epub.

Ginsberg, Y., Långström, N., Larsson, H., \& Lichtenstein, P. (2013). ADHD and criminality: Could treatment benefit prisoners with ADHD who are at higher risk of reoffending? (Review). Expert Review of Neurotherapeutics 13(4), 345-348. https://doi.org/10.1586/ern.13.22

Haertling, F., Müller, B., \& Bilke-Hentsch, O. (2015). Effectiveness and safety of a long-acting, once-daily, two-phase release formulation of methylphenidate (Ritalin ${ }^{\circledR}$ LA) in school children under daily practice conditions. Attention Deficit and Hyperactivity Disorders 7(2), 157-164. Doi: 10.1007 / s12402-014-0154-x.

Hejduková, P., \& Kureková, L. (2017). Performance and sustainable of healthcare systems and approaches to its measuring and evaluating. International Journal of Social Sciences 6(2), 32-43., 10.20472/SS.2017.6.2.003

Henke, G. (2017). Kriminalität. Island steht nach Mord an einer jungen Frau unter Schock. https://www.shz.de/deutschland-welt/panorama/island-steht-nach-mord-an-einer-jungenfrau-unter-schock-id15911216.html [6.8.2017].

International Narcotics Control Board / INCB (2016). Annual report 2016 INCB. https://www.incb.org/incb/en/...reports/annual-report-2016.html [02.03.2018].

Klassen, A., Miller, A., Raina, P., Lee, S.K., \& Olsen, L. (1999). Attention-Deficit/Hyperactivity Disorder in Children and Youth: A Quantitative Systematic Review of the Efficacy of Different Management Strategies. Canadian Journal of Psychiatry 44, 1007-1016. https://doi.org/10.1177/070674379904401007

Klein, J.P. (2017). ADHS: Beginn auch im Erwachsenenalter? Psychotherapie Psychosomatik Medizinische Psychologie PmP 67, 183-184. https://doi.org/10.1055/s-0043-107805

Krogh, H.B., Storebø, O.J., Faltinsen, E., Todorovac, A., Ydedahl-Jensen, E., Magnusson, F.L., Holmskov, M., Gerner, T., Gluud, C., \& Simonsen, E. (2019). Methodological advantages and disadvantages of parallel and crossover randomised clinical trials on methylphenidate for attention deficit hyperactivity disorder: a systematic review and meta-analyses. BMJ Open. Mar 30;9(3):e026478. doi: 10.1136/bmjopen-2018-026478.

Lichtenstein, P., Halldner, L., Zetterqvist, J., Sjölander, A., Serlachius, E., Fazel, S., Långström, N., \& Larsson, H. (2012). Medication for Attention Deficit-Hyperactivity Disorder and Criminality. New England Journal of Medicine 367, 2006-2014. https://doi.org/10.1056/NEJMoa1203241

Ljung, T., Chen, Q., Lichtenstein, P., \& Larsson, H. (2014). Common etiological factors of attention-deficit/hyperactivity disorder and suicidal behavior: a population-based study in Sweden. JAMA Psychiatry 71, 958-964. https://doi.org/10.1001/jamapsychiatry.2014.363 
Lundstrom, S., Forsman, M., Larsson, H., Kerekes, N., Serlachius, E., Langstrom, N., \& Lichtenstein, P. (2014). Childhood neurodevelopmental disorders and violent criminality: a sibling control study. Journal Autism Developmental Disorders 44, 2707-2716. https://doi.org/10.1007/s10803-013-1873-0

Man, K.K., Chan, E.W., Coghill, D., Douglas, I., Ip, P., Leung, L.-P., \& Wong, I.C. (2015). Methylphenidate and the risk of trauma. Pediatrics 135, 40-48. https://doi.org/10.1542/peds.2014-1738

Manuzza, S., Klein, R.G., Giampino, T.L. (1989). Hyperactive boys almost grown up. Criminality and its relationship to psychiatric status. Archives of General Psychiatry 46, 1073-1079. https://doi.org/10.1001/archpsyc. 1989.01810120015004

Meier, B.-D. (2016). Kriminologie, 5. Auflage. München: C.H. Beck.

Moffit, T.E., Houts, R., \& Asherson, P. et al. (2015). Is Adult ADHD a Childhood-Onset Neurodevelopmental Disorder? Evidence from a Four-Decade Longitudinal Cohort Study. $\begin{array}{llll}\text { American Journal } & \text { Psychiatry } & \text { 967-977. }\end{array}$ https://doi.org/10.1176/appi.ajp.2015.14101266

Mohr-Jensen, C., \& Steinhausen, H.C. (2016). A meta-analysis and systematic review of the risk associated with childhood attention-deficit hyperactivity disorder on long-term outcome of arrest, convictions, and incarcerations. Clinical Psychology Review 48, 32-42. https://doi.org/10.1016/j.cpr.2016.05.002

Neuy-Barthmann, A. (2012). ADHS/ADS. http://www.adhs-deutschland.de/Home/ADHS/ADHSADS/ADHS.aspx [07.08.2017].

Nienhaus, L. (2007). Ritalin. Die Karriere einer Pille. Frankfurter Allgemeine Zeitung, 02.10.2007.

Nützel, J., Schmidt, M., Goldbeck, L., \& Fegert, M. (2005). Kinder- und jugendpsychiatrische Versorgung von psychisch belasteten Heimkindern. Praxis der Kinderpsychologie und Kinderpsychiatrie 54, 627-644.

Ostendorf, H. (2011). Jugendstrafrecht. Nomos, Baden-Baden.

Pappadopulos, E., Woolston, S., Chait, A., Perkins, M., Connor, D.F. \& Jensen, P.S. (2006). Pharmacotherapy of aggression in children and adolescents: Efficacy and effect size. Journal of the Canadian Academy of Child and Adolescent Psychiatry = Journal de I'Academie canadienne de psychiatrie de l'enfant et de l'adolescent 15, 27-39.

Pfeiffer, C. (Interviewte) \& Heitmüller, U. (Interviewerin) (2013). Je christlicher die Eltern, desto weniger Prügel fürs Kind? 04.06.2013, www.heise.de/tp/artikel/39/39248/1.html. [03.03.2018]

Philipp-Wiegmann, J., Rösler, M., Clasen, O., Zinnow, T., Retz-Junginger, P., \& Retz, W. (2017). $A D H D$ modulates the course of delinquency: a 15 year follow-up study of young incarcerated man. European Archives of Psychiatry and Clinical Neuroscience. Doi: 10.1007/s00406-017-0819-5.

Preuss, U. (2007). Aufmerksamkeits- und Hyperaktivitätsstörung für Neurologen - Übersicht über ADHS bei Kindern, Jugendlichen und Erwachsenen. Aktuelle Neurologie 34, 291-310. https://doi.org/10.1055/s-2007-970815 
Retz, W., Retz-Junginger, P., Hengesch, G., Schneider, M., Thome, J., Pajonk, F.G., \& Rösler, M. (2004). Psychometric and psychopathological characterization of young male prison inmates with and without attention deficit / hyperactivity disorder. European Archives of Psychiatry and Clinical Neuroscience 254, 365-371. https://doi.org/10.1007/s00406-0040470-9

Retz, W., \& Rösler, M. (2010). Association of ADHD with reactive and proactive violent behavior in a forensic population. Attention Deficit Hyperactivity Disorder 2, 195-202. https://doi.org/10.1007/s12402-010-0037-8

Rösler, M., Retz, W., Retz-Junginger, P., Hengesch, G., Schneider, M., Supprian T., \& Thome, J. (2004). Prevalence of attention deficit-/hyperactivity disorder (ADHD) and comorbid disorders in young male prison inmates. European Archives of Psychiatry and Clinical Neuroscience 254, 365-371. https://doi.org/10.1007/s00406-004-0516-Z

Satterfield, J.H., Faller, K.J., Crinella, F.M., Schell, A.M., Swanson, J.M., \& Homer, L.D. (2007). A 30-year prospective follow-up study of hyperactive boys with conduct problems: adult criminality. Journal of the American Academy of Child and Adolescent Psychiatry 46(5), 601-610. https://doi.org/10.1097/chi.0b013e318033ff59

Sarnes, M. (2013). Störungskonzepte bei Kindern und Jugendlichen mit $A D(H) S$ - aus der Perspektive von Ärzten und Therapeuten, Lehrkräften und Eltern. Diss Universität Köln 2012/13. Regensburg: Roderer Verlag.

Schlander, M. (2007). Aktuelle Daten zur medizinischen Versorgung von Kindern und Jugendlichen mit ADHS in Deutschland - Administrative Prävalenz, beteiligte Arztgruppen und Arzneimitteltherapie. Psychoneuro 33, 412-415. https://doi.org/10.1055/s-2007993824

Schwabe, U., \& Paffrath, D. (Hrsg.) (2011). Arzneimittelverordnungs-Report 2011: Aktuelle Daten, Kosten, Trends und Kommentare. Berlin, Heidelberg: Springer. https://doi.org/10.1007/978-3-642-21992-4

Schwind, H.-D. (2013). Kriminologie. Eine praxisorientierte Einführung mit Beispielen. 22. Aufl. Heidelberg u.a.: Kriminalistik.

Sonuga-Barke, E.J., Brandeis, D., Cortese, S., Daley, D., Ferrin, M., Holtmann, M., \& Döpfner, M. (2013). Nonpharmacological interventions for ADHD: systematic review and meta-analysis of randomized controlled trails of dietary and psychological treatments. American Journal of Psychiatry 170, 275-289. https://doi.org/10.1176/appi.ajp.2012.12070991

Tracy, P.E., Wolfgang, M.E., \& Figlio, R. M. (1990). Delinquency Careers in Two Birth Cohorts. Plenum Press, New York, London. https://doi.org/10.1007/978-1-4684-7050-5

Tye, K.M., Tye, L.D., Cone, J.J., Hekkelman, E.F., Janak, P.H., \& Bonci, A. (2010). Methylphenidate facilitates learning-induced amygdala plasticity. Nature neuroscience 13, 475-481. https://doi.org/10.1038/nn.2506

Young, S., Moss, D., Sedgwick, O., Fridman, M., \& Hodgkins, P. (2015). A meta-analysis of the prevalence of attention deficit hyperactivity disorder in incarcerated populations. Psychological Medicine 45, 247-258. https://doi.org/10.1017/S0033291714000762 
Van der Oord, S., Prins, P.J.M., Oosterlaan, J., \& Emmelkamp, P.M.G. (2008). Efficacy of Methylphenidate, Psychosocial Treatments and their Combination in School-aged Children with ADHD: A Meta-analysis. Clinical Psychology Review 28, 783-800. https://doi.org/10.1016/j.cpr.2007.10.007

Weiss, G., Hechtman, L., Milroy, T., \& Perlman, T. (1985). Psychiatric status of hyperactive children. Journal of the American Academic Child and Adolescent Psychiatry 24, 211-220. https://doi.org/10.1016/S0002-7138(09)60450-7

Weydt, E. (2018). In 20 Wochen Wartezeit kann viel passieren. NDR info, 10.04.2018, https://www.ndr.de/ratgeber/gesundheit/In-20-Wochen-Wartezeit-kann-vielpassieren,psychotherapie164.html [27.04.2018]

Wolfgang, M. E., Figlio, R.M., \& Sellin, T. (1972). Delinquency in a Birth Cohort. University of Chicago Press, Chicago.

Ziegler, E., Blocher, D., Henkel, K., \& Rösler, M. (2003). Symptome aus dem Spektrum des hyperkinetischen Syndroms bei Häftlingen einer Justizvollzugsanstalt. Recht \& Psychiatrie 21, 17-21.

Zittlau, J. (2015). Nebenwirkungen. So gefährlich sind die beliebtesten Medikamente. Welt, 19.03.2015, http://www.welt.de/gesundheit/article138568439/So-gefaehrlich-sind-diebeliebtesten-Medikamente.html [03.03.2018]. 